\section{Compliance with ethical standards}

Conflict of interest The authors declare that they have no conflict of interest.

\section{References}

1. Meel R, Dhiman R. Proposal for a new classification for ocular surface squamous neoplasia. Eye. 2018;32:1284-5.

2. Shields CL, Chien JL, Surakiatchanukul T, Sioufi K, Lally SE, Shields JA. Conjunctival tTumors: review of clinica features, risks, biomarkers, and outcomes - the 2017 J.Donald M. Gass LLecture. Asia Pac J Ophthalmol. 2017;6:109-20.

3. El-Assal KS, Salvi SM, Rundle PA, Mudhar HS, Rennie IG. Treatment of invasive ocular surface squamous neoplasia with proton beam therapy. Eye. 2013 Oct;27(10):1223.

4. Graue GF, Tena LB, Finger PT. elElectron beam radiation for conjunctival squamous carcinoma. Ophthal Plas Reconstr Surg. 2011;27:277-81.

5. Bellerive C, Berry JL, Polski A, Singh AD. Conjunctival squamous neoplasia: staging and initial treatment. Cornea. 2018. https://doi. org/10.1097/ICO.0000000000001651.

\title{
Response to 'Comment on: Proposal for a new classification for ocular surface squamous neoplasia'
}

\author{
Rachna Meel ${ }^{1} \cdot$ Rebika Dhiman $^{1}$ \\ Published online: 19 October 2018 \\ (c) The Royal College of Ophthalmologists 2018
}

We thank McGrath and Salvi [1] for their valuable comments and suggestions.

There are no published guidelines for treatment of ocular surface squamous neoplasia (OSSN). Also, clinical spectrum of OSSN varies significantly between different continents like Africa and North America or Australia [2]. Clinical presentation is significantly delayed in resource-constrained countries, and hence use of conservative management options like plaque brachytherapy are not only limited by availability but also by feasibility.

The conventional method of treatment for OSSN is wide local surgical excision using a 'no touch technique' and cryotherapy of conjunctival edges. Topical treatment with chemotherapeutic agents and interferons has become popular in the past 1-2 decades due to the inherent benefits of topical treatment-treatment of a complete ocular surface, thus reducing the chances of microscopic residual disease, lesser side effects of treatment as compared to surgical excision, especially in giant or diffuse tumors and the relative ease of

Rachna Meel

dr.rachnameel@gmail.com

1 Oculoplasty and Ocular Oncology Services, Dr R P Centre for Ophthalmic Sciences, All India Institute of Medical Sciences, New Delhi 110029, India administering treatment. Traditionally, enucleation is done for tumors with intraocular extension and exenteration for OSSN with orbital extension.

We agree with the authors that, technology-dependent treatment modalities, like plaque brachytherapy and proton beam therapy may not be available in resource-constrained countries. There are adequate reports in literature to show that brachytherapy effectively controls OSSN invading into the ocular coats and hence may be used as an adjuvant treatment in cases with incomplete tumor resection (Table 1) (the same has been added in the treatment options for grade II tumor in the revised table) [3]. However, its use in OSSN with overt (obvious on imaging (UBM) or clinically) intraocular extension is still being explored and needs to be evaluated in further studies [4]. We, at our center are now using adjuvant plaque brachytherapy in cases of invasive SCC, where there is microscopic residual disease in the ocular coats after surgery.

The proposed classification attempts to address the concerns with AJCC classification, as reported by previous studies and intends to give a rough guideline for treatment based on most commonly available treatment modalities [4]. While enucleation and exenteration remain the most common method of treatment for tumor with ocular and orbital extension, respectively, the treatment scenario for OSSN with 
Table 1 Proposal for the new classification (revised)

\begin{tabular}{llllll}
\hline Group/grade & $\begin{array}{l}\text { Limbal } \\
\text { involvement } \\
\text { (clock hours) }\end{array}$ & $\begin{array}{l}\text { Maximal } \\
\text { basal } \\
\text { diameter } \\
(\mathrm{mm})\end{array}$ & Imaging findings & Treatment recommended & Risk with upfront surgical \\
excision
\end{tabular}

Grade I: OSSN with no invasion into ocular coats clinically $\%$ on imaging (UBM)

\begin{tabular}{|c|c|c|c|c|c|}
\hline A (Small) & $\leq 3$ & $\leq 5$ & $\begin{array}{l}\text { No invasion into } \\
\text { ocular coats/globe } \\
\text { on UBM }\end{array}$ & Surgical excision with edge control & Minimal risk of side effects \\
\hline B (Large) & $>3$ to $<6$ & $5-15$ & $\begin{array}{l}\text { No invasion into } \\
\text { ocular coats/globe } \\
\text { on UBM }\end{array}$ & Immunotherapy/Immunoreduction $\mathrm{f} / \mathrm{b}$ surgical excision & $\begin{array}{l}\text { Moderate risk of side effects } \\
\text { (Limbal stem cell deficiency, } \\
\text { symblepharon formation) }\end{array}$ \\
\hline C (Diffuse) & $\geq 6$ & $\geq 15$ & $\begin{array}{l}\text { No invasion into } \\
\text { ocular coats/globe } \\
\text { on UBM }\end{array}$ & Immunoreduction with interferons $\mathrm{f} / \mathrm{b}$ surgical excision & $\begin{array}{l}\text { High risk of side effects, high risk } \\
\text { of recurrence }\end{array}$ \\
\hline
\end{tabular}

Grade II: OSSN with invasion into ocular coats (sclera/corneal stroma) on imaging

Any Any Scleral or corneal Excision with lamellar sclerectomy or keratectomy stromal invasion on +cryotherapy of margins and base/adjuvant plaque UBM brachytherapy for residual tumor at base

Grade III: OSSN with intraocular invasion

$\begin{array}{lll}\text { Any Any } \quad \begin{array}{l}\text { Intraocular } \\ \text { involvement present } \\ \text { (clinically/UBM) }\end{array} & \end{array}$

Grade IV: OSSN with intraorbital extension

Any Any Orbital extension on Exenteration CT/MRI

$U B M$ ultrasound biomicroscopy, $C T$ computed tomography scan, $M R I$ magnetic resonance imaging, $f / b$ followed by

${ }^{\mathrm{a} C}$ Clinically as suggested by mobility of conjunctival lesions in non-limbal tumors

no or limited invasion has changed significantly. Surgery is mainly replaced with topical therapy or is used for residual disease after chemoreduction or immunoreduction. The proposed classification helps to decide treatment especially in this category. I thank the authors for picking up the printing error in Table 1 (grade II tumors are tumors with extension into ocular coats on UBM or clinically, the same has been corrected in the revised table).

Till the time, further studies evaluate and define the role of other possible treatment options for intraocular and orbital disease like external beam radiotherapy, brachytherapy, or intraorbital interferon injections for a possible staged management approach; this classification may help guide treatment with the more established treatment options $[5,6]$.

\section{Compliance with ethical standards}

Conflict of interest The authors declare that they have no conflict of interest.

\section{References}

1. McGrath LA, Salvi SM. Comment on: Proposal for a new classification for ocular surface squamous neoplasia. Eye. 2018. https:// doi.org/10.1038/s41433-018-0240-y

2. Shields CL, Chien JL, Surakiatchanukul T, Sioufi K, Lally SE, Shields JA. Conjunctival tumors: review of clinical features, risks, biomarkers, and outcomes - The 2017 J. Donald M. Gass Lecture. Asia Pac J Ophthalmol (Phila). 2017;6:109-20.

3. Walsh-Conway N, Conway RM. Plaque brachytherapy for the management of ocular surface malignancies with corneoscleral invasion. Clin Exp Ophthalmol. 2009;37:577-83.

4. Arepalli S, Kaliki S, Shields CL, Emrich J, Komarnicky L, Shields JA. Plaque radiotherapy in the management of scleral-invasive conjunctival squamous cell carcinoma: an analysis of 15 eyes. JAMA Ophthalmol. 2014;132:691-6.

5. Meel R, Dhiman R, Sen S, Sharma S. Immunoreduction of locally advanced orbito-conjunctival squamous cell carcinoma with intraorbital interferon alpha-2b injection: a globe saving approach. Clin Exp Ophthalmol. 2018;46:87-88.

6. Murthy R, Gupta H, Krishnatry R, Laskar S. Electron beam radiotherapy for the management of recurrent extensive ocular surface squamous neoplasia with orbital extension. Indian J Ophthalmol. 2015;63:672-4. 